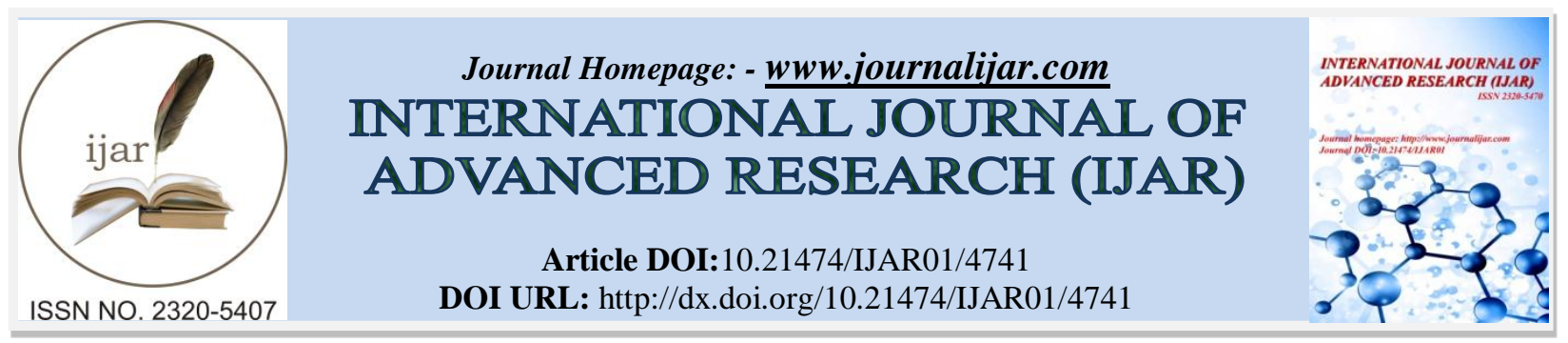

RESEARCH ARTICLE

\title{
CLUTCH CHARACTERISTICS AND EGG DIAMETRICS OF INDIAN POND HERON (ARDEOLA GRAYII) IN JAMMU REGION (J\&K).
}

\author{
Prof. D. N. Sahi ${ }^{1}$, Prof. Roopama Gandotra ${ }^{2}$, ${ }^{*}$ PawandeepKaur ${ }^{3}$ and Dr. Sakshi Koul ${ }^{4}$. \\ 1. Professor, Department of Zoology, University of Jammu. \\ 2. Head, Department of Zoology, University of Jammu. \\ 3. Research Scholar, Department of Zoology, University of Jammu. \\ 4. Research Scholar, Department of Zoology, University of Jammu.
}

\section{Manuscript Info}

\section{Manuscript History}

Received: 5 May 2017

Final Accepted: 7 June 2017

Published: July 2017

Key words:-

Clutch characteristics, Indian Pond

Heron, Egg diametrics and Egg weight.

\section{Abstract}

The present study on clutch characteristics and egg diametrics of Indian Pond Heron (Ardeola grayii) was conducted for three consecutive years i.e., 2013, 2014 and 2015 in five different stations viz., station I (Haripur), station II (Mansar), station III (Gharana), station IV (Kalyana) and station V (Gho Manhasa) during the breeding season which commenced from May up to September. The overall mean clutch size was recorded to be $3.71 \pm 1.06$ varying from 1 to 5 . The clutch size was found to vary among different stations viz., $3.73 \pm 0.76(\mathrm{n}=41)$ at station I, $4.07 \pm 0.73(\mathrm{n}=14)$ at station II, 3.68 \pm $0.88(\mathrm{n}=38)$ at station III, $3.71 \pm 0.85(\mathrm{n}=32)$ at station IV and 3.64 \pm $1.02(\mathrm{n}=17)$ at station $\mathrm{V}$. The eggs were recorded to be oval with greenish blue coloration and without any markings. Overall mean values of egg dimensions were recorded to be egg length $(3.90 \pm 0.16$ $\mathrm{cm})$, egg breadth $(2.78 \pm 0.19 \mathrm{~cm})$, egg volume $\left(15.57 \pm 2.41 \mathrm{~cm}^{3}\right)$, egg shape index $(71.45 \pm 4.95)$ and egg weight $(17.93 \pm 2.71 \mathrm{gm})$. A statistically significant correlation was registered between egg length and egg volume $(\mathrm{r}=0.4852)$ as well as between egg breadth and egg volume $(r=0.8274)$.

Copy Right, IJAR, 2017,. All rights reserved.

\section{Introduction:-}

Indian Pond Heron (Ardeola grayii) commonly known as "Paddy bird" belongs to family Ardeidae of Order Pelecaniformes. It is commonly seen frequenting paddy fields, ponds, reservoirs and other natural wetlands. It usually escapes notice by its dingy coloration until it springs to life with a flash of white wings. It is found throughout much of the Indian sub-continent except parts of northwest, northeast and Himalayas upto 2150m in Nilgiris and $1500 \mathrm{~m}$ in Himalayas (Grimett et al. 1998). In many bird species, egg size is often considered an important index of egg quality and is correlated with the survival of their offspring (Murton et al., 1974: Amat et al., 2001). Clutch size is one of the fundamental elements of the reproductive strategy of a species, as it represents the number of offsprings that a pair endeavours to produce in a reproductive attempt (Anderson, 2006). Egg size and clutch size in birds can vary with several factors that include ambient temperature, genetic component, female mass and body condition, parental age, seasonal variations, climate change and nutrient constraints (O' Connor, 1979; Hill 1984; Jarvinen, 1991; Amat et al., 2001, Styrsky et al., 2002; Dolenec, 2004 and Saino et al., 2004). The studies on 
egg and clutch characteristics are of paramount importance in determining the reproductive success of a species as the combination of egg size and clutch size determines the total energetic investment in clutch formation by a female (Flint and Sedinger, 1992). Thus, the present investigation was conducted to study clutch characteristics and egg diametrics and to analyse the correlation between various egg variables.

\section{Materials and methods:-}

\section{Study Area:-}

The present study was conducted in district Jammu of J\&K State. Geographically, it lies between $32^{\circ} 27^{\prime}$ and $33^{\circ} 30^{\prime}$ $\mathrm{N}$ latitude and $74^{\circ} 19^{\prime}$ and $75^{\circ} 20^{\prime} \mathrm{E}$ longitude. Altitudinally, it extends from 250 meters to 410 meters above mean sea level. During the period of present investigation, five stations were selected in the study area.

1. Station- I: Haripur: The latitude and longitude of this station are $32^{\circ} 36^{\prime} 27.56^{\prime \prime} \mathrm{N}$ and $74^{\circ} 43^{\prime} 57.29^{\prime \prime} \mathrm{E}$ respectively and it is located at an altitude of 271 meters from mean sea level. The station is at a distance of 31 $\mathrm{km}$ from Jammu city. The main water source at this station is Ranbir Canal.

2. Station-II: Mansar: This station is located at a distance of $64 \mathrm{~km}$ east of Jammu city. It lies between $32^{\circ} 41^{\prime} 48.36^{\prime \prime} \mathrm{N}$ latitude and $75^{\circ} 08^{\prime} 44.70^{\prime \prime}$ E longitude at an elevation of $666 \mathrm{~m}$ above msl. This lake harbours characteristic icthyofauna, amphibians and reptiles and has an intimate association with the wildlife and wild avifauna migratory and non- migratory of the area.

3. Station-III: Gharana, R.S. Pura: It is situated between $32^{\circ} 36^{\prime} 51.52^{\prime \prime} \mathrm{N}$ latitudes and $74^{\circ} 38^{\prime} 58.15^{\prime \prime}$ E longitudes. It is located at an elevation of 251 meters from msl. It is at a distance of $35 \mathrm{~km}$ from Jammu city.

4. Station-IV: Kalyana: The latitude 32 $49^{\prime} 62.69^{\prime \prime}$ and longitude $74^{\circ} 73^{\prime} 66.33^{\prime \prime}$ are the geo-coordinates of this station. It is at a distance of $26.6 \mathrm{~km}$ from Jammu city. The major area of this station is under cultivation.

5. Station-V: Gho-Manhasa: This station lies between $32^{\circ} 43^{\prime} 39.59^{\prime \prime} \mathrm{N}$ latitude and $74^{\circ} 45^{\prime} 41.36^{\prime \prime}$ E longitude at an altitude of $311 \mathrm{~m}$ above the mean sea level. It is at a distance of $10.9 \mathrm{~km}$ from the Jammu city in Marh tehsil. The Gho-Manhasa stream is the main source of water at this station. The stream itself is fed by river Chenab and it traverses through the area supporting many villages. The stream harbours thick macrophytic vegetation and provide suitable habitat for many waterbirds particularly waders.

\section{Methodology:-}

Recurrent surveys were conducted to different stations from $0600 \mathrm{hrs}$ to $1200 \mathrm{hrs}$ in morning and $1300 \mathrm{hrs}$ to 1900 hrs in evening to record the data on clutch size and egg characteristics of Indian Pond Heron during three consecutive years from March 2013 to February 2016. The birds were observed with naked eye and through binoculars (Bushnell 7x 50 U.S.A. made). Moreover, photography was done with the aid of Canon EOS camera fitted with 300mm zoom lens and Nikon D 330 with $300 \mathrm{~mm}$ zoom lens. Moreover, the nests located were examined to record various egg parameters like shape, colour, texture, length, breadth and weight. Clutch size was recorded after laying had been completed.

1. Egg size and weight: The length and breadth of eggs were measured with the aid of Digital VernierCalliper and egg weight was recorded to the nearest $0.01 \mathrm{gm}$ with the help of an electronic weighing machine in the field.

2. Egg Volume: The egg volume (V) was calculated by using the formula developed by Hoyt (1979).

$$
\begin{gathered}
\mathrm{V}=0.51 \times \mathrm{LxB}^{2} \\
\text { Where } \mathrm{L}=\text { Length } \\
\mathrm{B}=\text { Breadth }
\end{gathered}
$$

3. Egg Shape Index (ESI): It was computed using the formula

$$
\mathrm{ESI}=\mathrm{B} / \mathrm{L} \times 100
$$

Statistical Analysis: The correlation between various egg variables were calculated using Pearson's correlation using SPSS 20 software.

\section{Results and discussion:-}

Breeding season of Indian Pond Heron (Ardeola grayii) commenced from May to September with June and July being the peak breeding months. A total of 142 nests were located in five study stations during March 2013 to February 2016. The nests were platform shaped generally made up of dried twigs and solid sticks but in some instances it was recorded to expend considerable effort for breaking leafy twigs and branches off the nesting tree itself. The nests were located near streams, marshes as well as agricultural fields. 


\section{Clutch characteristics:-}

During the present study period, clutch size was recorded to vary from 1 to 5 with a mean clutch size of $3.71 \pm 1.06$. Among 142 nests studied, clutch size of 4 eggs per nest was reported to be the most common $(n=70)$ with a percent share of $49.29 \%$ followed by clutch size of $3(n=33)$ contributing $23.23 \%$. Moreover, there were 26 nests with clutch size of $5(18.30 \%) ; 9$ nests with clutch size of $2(6.33 \%)$ and 4 nests with clutch size of $1(2.81 \%)$. Thus, it is evident from table-1 that nests with clutch size of 4 were significantly more common. The clutch size of herons may differ between years (Custer et al., 1983) or it may remain constant (Tremblay and Ellison, 1980). Earlier workers Whistler (1949) and Ali and Ripley (1969) have reported the clutch size to be 4 to 6. Seedikkoya et al. (2008) have recorded the clutch size of 3 to be the most common. Jaman (2012) ascertained the clutch size to range from 3 to 4 eggs with an average of 3.7 eggs. Fazilli (2014) however observed clutch size of Indian Pond Heron to vary from 2 to 6 with an average of $3.47 \pm 0.98$. In the present study, the mean clutch size was however recorded to vary during three breeding seasons viz., $3.8 \pm 0.78$ in $2013,3.74 \pm 0.85$ in 2014 and $3.67 \pm 1.0$ in 2015. Besides, the average

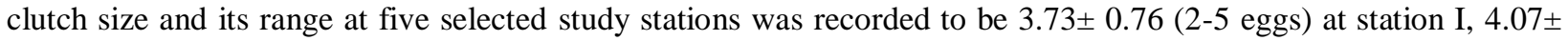
0.73 (3-5 eggs) at station II, $3.68 \pm 0.88$ (1 to 5 eggs) at station III, $3.71 \pm 0.85$ (1 to 5 eggs) at station IV and 3.64 \pm 1.02 (1 to 5 eggs) at station V (Table- 2). Klomp (1970) stated that the mean clutch size in birds can vary with different factors like food supply, habitat, population density, age of the breeding adults, latitude, longitude and altitude. The present findings are in consonance with Zhao et al. (2002 b) and Du B et al. (2014) who stated that clutch size in birds can vary with different factors.

\section{Egg Diametrics:-}

The eggs of Indian Pond Heron were oval in shape with one end broader and other end slightly pointed. They were greenish blue in colour without any markings. The texture of eggs was smooth. The present findings are in consonance with that reported by Yesmin et al. (2001), Seedikkoya et al. (2008) and Fazili (2014). Moreover, egg laying pattern was studied on daily basis which revealed that Indian Pond Heron laid one egg in a day usually during night or early morning hours at an interval of $24 \mathrm{hrs}$ until the clutch was completed. Similar findings were putforth by Seedikkoya et al. (2008) and Fazili (2014). Same egg laying pattern has been reported for a number of other avian species (Prather and Cruz, 1995 and Kumar et al., 1999). The average length of 150 eggs was measured to be $3.90 \pm 0.17 \mathrm{~cm}$ ranging from 3.5 to $4.2 \mathrm{~cm}$. The average breadth was $2.78 \pm 0.19 \mathrm{~cm}$ ranging from $2.4-3.2 \mathrm{~cm}$. The average egg weight was recorded to be $17.93 \pm 2.71 \mathrm{gm}$ ranging from 14.18- 24.37 gms. Furthermore, the egg volume was calculated to be $15.57 \pm 2.41 \mathrm{~cm}^{3}$ with minimum 10.86 and maximum $20.88 \mathrm{~cm}^{3}$ while egg shape index was determined to be $71.45 \pm 4.95$ with minimum 58.53 and maximum 83.78 (Table-3). Besides, the mean egg dimensions recorded at five different study stations were as follows: At Station-I, the mean length, breadth, weight, egg volume and egg shape index of 40 eggs was $3.91 \pm 0.15 \mathrm{~cm}, 2.71 \pm 0.18 \mathrm{~cm}, 17.63 \pm 2.95 \mathrm{gm}$ and $14.82 \pm 2.33 \mathrm{~cm}^{3}$ and $69.47 \pm 4.51$ respectively; at Station-II, dimensions of 17 eggs were $3.91 \pm 0.20 \mathrm{~cm}, 2.61 \pm 0.12 \mathrm{~cm}, 19 \pm 1.81 \mathrm{gm}$, $13.92 \pm 1.56 \mathrm{~cm}^{3}$ and $67.28 \pm 4.69$ respectively and at Station-III, egg diametrics of 30 eggs were $3.89 \pm 0.16 \mathrm{~cm}$, $2.82 \pm 0.20 \mathrm{~cm}, 16.94 \pm 2.88 \mathrm{gm}, 15.76 \pm 2.34 \mathrm{~cm}^{3}$ and $72.38 \pm 6.02$ respectively. Moreover, the mean values of egg dimensions at Station-IV $(\mathrm{n}=43)$ and Station-V $(\mathrm{n}=20)$ were $3.9 \pm 0.16 \mathrm{~cm}, 2.84 \pm 0.16 \mathrm{~cm}, 17.98 \pm 2.61 \mathrm{gm}, 16.18 \pm$ $2.31 \mathrm{~cm}^{3}$ and $72.99 \pm 3.34$ and $3.92 \pm 0.18 \mathrm{~cm}, 2.9 \pm 0.14 \mathrm{~cm}, 18.97 \pm 2.07 \mathrm{gm}, 16.91 \pm 2.19 \mathrm{~cm}^{3}$ and $73.94 \pm 3.23$ respectively (Table-2).

\section{Correlation between various egg variables studied:-}

A statistically significant and strong positive correlation was recorded between egg length and egg volume ( $\mathrm{r}=$ $0.4852)$ as well as between egg breadth and egg volume ( $r=0.8274)$. The egg weight also had a positive correlation with egg length $(r=0.125)$ while a negative insignificant correlation with egg shape index $(r=-0.070)$. Besides, a strong negative correlation was reported between egg length and egg shape index $(r=-0.339)$. Panda (1996) stated that egg length and egg shape index have negative relationship because egg length is the denominating factor in estimating shape index. However, a strong positive correlation was registered between egg breadth and egg shape index $(r=0.788)$ and plausible reason for this might be the fact that shape index is directly proportional to egg breadth. The correlations between egg length and egg breadth $(r=0.301)$ were also statistically significant (Table-4).

\section{Conclusion:-}

From the present study it can be inferred that the optimum clutch size of Indian Pond Heron (Ardeola grayii) was recorded to be 4 and showed significant positive correlation between egg length and egg volume.

\section{Acknowledgement:-}

The authors are highly thankful to the Department of Zoology, University of Jammu, Jammu for providing necessary facilities to carry out the study. 
Table1:- Frequency and percentage distribution of different clutch sizes of Indian Pond Heron (Ardeola grayii) in five study stations during 2013-2016.

\begin{tabular}{|c|c|c|c|c|c|c|c|c|c|c|c|}
\hline \multirow[b]{3}{*}{ Stations } & \multicolumn{10}{|c|}{ Clutch Size } & \multirow{3}{*}{$\begin{array}{l}\text { Total } \\
\text { number } \\
\text { of nests } \\
\text { studied }\end{array}$} \\
\hline & \multicolumn{2}{|l|}{1} & \multicolumn{2}{|l|}{2} & \multicolumn{2}{|l|}{3} & \multicolumn{2}{|l|}{4} & \multicolumn{2}{|l|}{5} & \\
\hline & $\begin{array}{l}\text { No. of } \\
\text { nests }\end{array}$ & $\%$ & $\begin{array}{l}\text { No. of } \\
\text { nests }\end{array}$ & $\%$ & $\begin{array}{l}\text { No. of } \\
\text { nests }\end{array}$ & $\%$ & $\begin{array}{l}\text { No. of } \\
\text { nests }\end{array}$ & $\%$ & $\begin{array}{l}\text { No. of } \\
\text { nests }\end{array}$ & $\%$ & \\
\hline I & - & - & 2 & 4.87 & 13 & 31.70 & 20 & 48.78 & 6 & 14.63 & 41 \\
\hline II & - & - & - & - & 3 & 21.42 & 7 & 50 & 4 & 28.57 & 14 \\
\hline III & 1 & 2.63 & 2 & 5.26 & 9 & 23.68 & 21 & 55.26 & 5 & 13.15 & 38 \\
\hline IV & 2 & 6.25 & 2 & 6.25 & 9 & 28.12 & 13 & 40.62 & 6 & 18.75 & 32 \\
\hline $\mathbf{V}$ & 1 & 5.88 & 1 & 15.88 & 4 & 23.52 & 8 & 47.05 & 3 & 17.64 & 17 \\
\hline
\end{tabular}

Fig. 1:- Histogram showing overall percentage of different clutches of Indian Pond Heron during the study period.

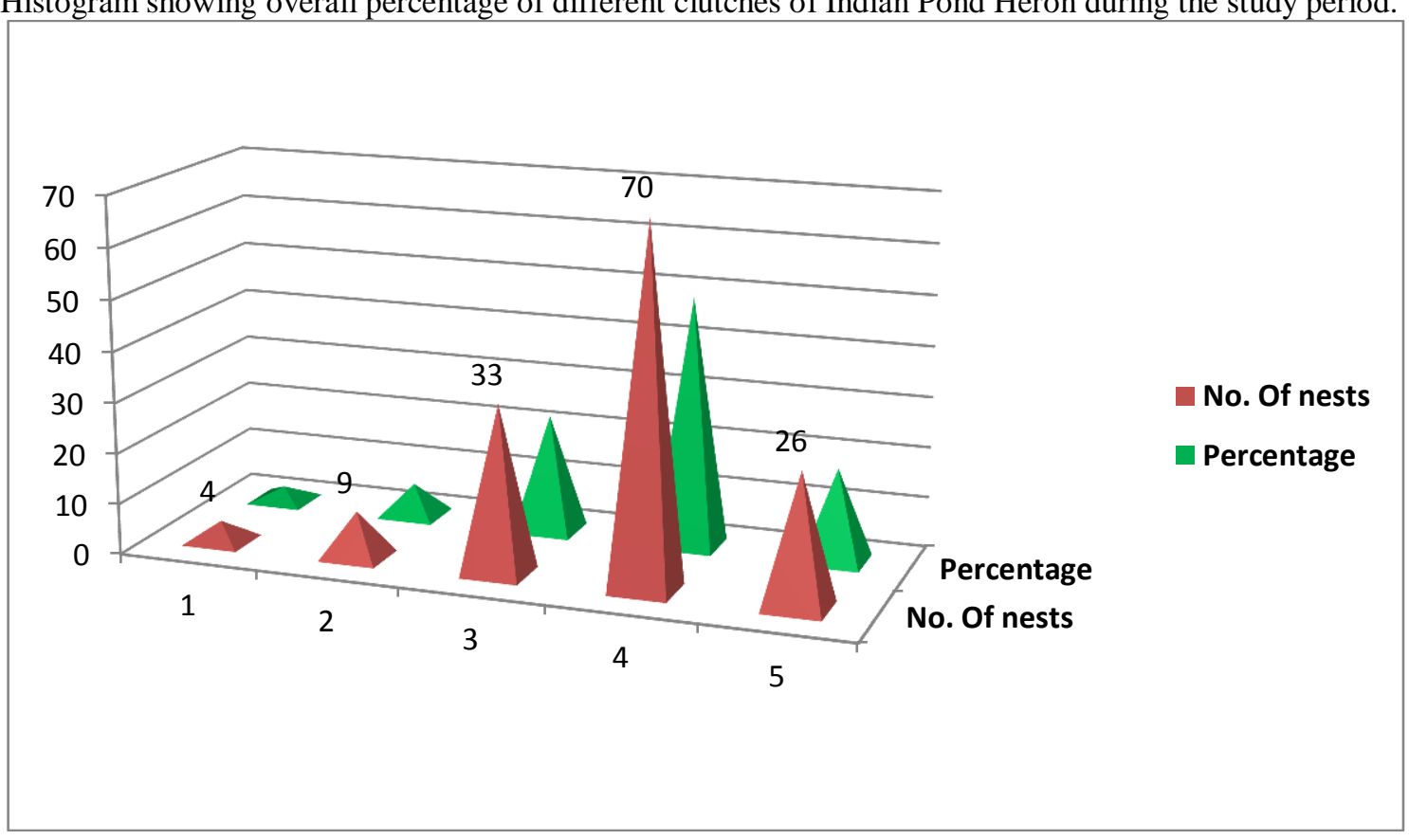

Table2:- Clutch characteristics and egg diametrics of Indian Pond Heron (Ardeola grayii) during 2013- 2016.

\begin{tabular}{|c|c|c|c|c|c|c|c|c|}
\hline Stations & $\begin{array}{l}\text { Total } \\
\text { No. of } \\
\text { nests }\end{array}$ & $\begin{array}{l}\text { Mean } \\
\text { clutch } \\
\text { size } \pm \text { SD }\end{array}$ & $\begin{array}{l}\text { Clutch } \\
\text { size } \\
\text { range }\end{array}$ & $\begin{array}{l}\text { Mean } \\
\text { Egg } \\
\text { length } \\
(\mathrm{cm}) \pm \text { SD }\end{array}$ & $\begin{array}{l}\text { Mean } \\
\text { Egg } \\
\text { breadth } \\
(\mathrm{cm}) \pm \text { SD }\end{array}$ & $\begin{array}{l}\text { Mean Egg } \\
\text { Volume } \\
\left(\mathrm{cm}^{3}\right) \pm \text { SD }\end{array}$ & $\begin{array}{l}\text { Mean } \\
\text { Shape } \\
\text { Index } \pm \\
\text { SD }\end{array}$ & $\begin{array}{lr}\text { Mean } & \text { Egg } \\
\text { Wt. } & \text { (gm) } \pm \\
\text { SD } & \end{array}$ \\
\hline I & 41 & $3.73 \pm 0.76$ & $2-5$ & $\begin{array}{l}3.91 \pm \\
0.15\end{array}$ & $2.71 \pm 0.18$ & $\begin{array}{l}14.82 \pm \\
2.33\end{array}$ & $\begin{array}{l}69.47 \pm \\
4.51\end{array}$ & $17.63 \pm 2.95$ \\
\hline II & 14 & $4.07 \pm 0.73$ & 3-5 & $3.91 \pm 0.20$ & $\begin{array}{l}2.61 \pm \\
0.12\end{array}$ & $\begin{array}{l}13.92 \pm \\
1.56\end{array}$ & $\begin{array}{l}67.28 \pm \\
4.69\end{array}$ & $19 \pm 1.81$ \\
\hline III & 38 & $3.68 \pm 0.88$ & $1-5$ & $\begin{array}{l}3.89 \pm \\
0.16\end{array}$ & $2.82 \pm 0.20$ & $\begin{array}{l}15.76 \pm \\
2.34\end{array}$ & $\begin{array}{l}72.38 \pm \\
6.02\end{array}$ & $16.94 \pm 2.88$ \\
\hline IV & 32 & $3.71 \pm 0.85$ & $1-5$ & $3.9 \pm 0.16$ & $2.84 \pm 0.16$ & $\begin{array}{l}16.18 \pm \\
2.31\end{array}$ & $\begin{array}{l}72.99 \pm \\
3.34\end{array}$ & $17.98 \pm 2.61$ \\
\hline $\mathbf{V}$ & 17 & $3.64 \pm 1.02$ & $1-5$ & $3.92 \pm 0.18$ & $2.9 \pm 0.14$ & $\begin{array}{l}16.91 \pm \\
2.19\end{array}$ & $\begin{array}{l}73.94 \pm \\
3.23\end{array}$ & $18.97 \pm 2.07$ \\
\hline
\end{tabular}


Table3:- Overall mean and range values of clutch size and egg dimensions of Indian Pond Heron during the study period.

\begin{tabular}{|l|l|l|l|l|l|l|}
\hline $\begin{array}{l}\text { Total } \\
\text { no. of } \\
\text { nests }\end{array}$ & $\begin{array}{l}\text { Clutch size } \\
(\text { Mean } \pm \text { SD) }\end{array}$ & $\begin{array}{l}\text { Egg } \\
\text { length }(\mathbf{c m}) \\
(\text { Mean } \pm \text { SD) }\end{array}$ & $\begin{array}{l}\text { Egg } \\
\text { breadth }(\mathbf{c m}) \\
(\text { Mean } \pm \text { SD) }\end{array}$ & $\begin{array}{l}\text { Egg Wt.(gm) } \\
(\text { Mean } \pm \text { SD })\end{array}$ & $\begin{array}{l}\left.\text { Egg Vol.(cm } \mathbf{3}^{3}\right) \\
(\text { Mean } \pm \text { SD })\end{array}$ & $\begin{array}{l}\text { Egg } \\
\text { Index } \\
(\text { Mean } \pm \text { SD) }\end{array}$ \\
\hline 142 & $3.71 \pm 1.06$ & $3.90 \pm 0.17$ & $2.78 \pm 0.19$ & $17.93 \pm 2.71$ & $15.57 \pm 2.41$ & $71.45 \pm 4.95$ \\
\hline Range & $1-5$ & $3.5-4.2$ & $2.4-3.2$ & $14.18-24.37$ & $10.86-20.88$ & $58.53-83.78$ \\
\hline
\end{tabular}

Table-4: Pearson's correlation coefficients (2- tailed) between egg variables.

\begin{tabular}{|l|l|l|l|l|}
\hline Variables & Egg Breadth & Egg Weight & Egg Volume & Egg Shape Index \\
\hline Egg Length & $0.3016^{* *}$ & 0.1253 & $0.4852^{* *}$ & -0.339 \\
\hline Egg Breadth & - & 0.001 & $0.8274^{* *}$ & $0.7885^{* *}$ \\
\hline Egg Volume & - & 0.006 & - & $0.5061^{* *}$ \\
\hline Egg Shape Index & - & -0.070 & - & - \\
\hline
\end{tabular}

$* *$ Statistical significance at level $\mathrm{p}<0.01$.

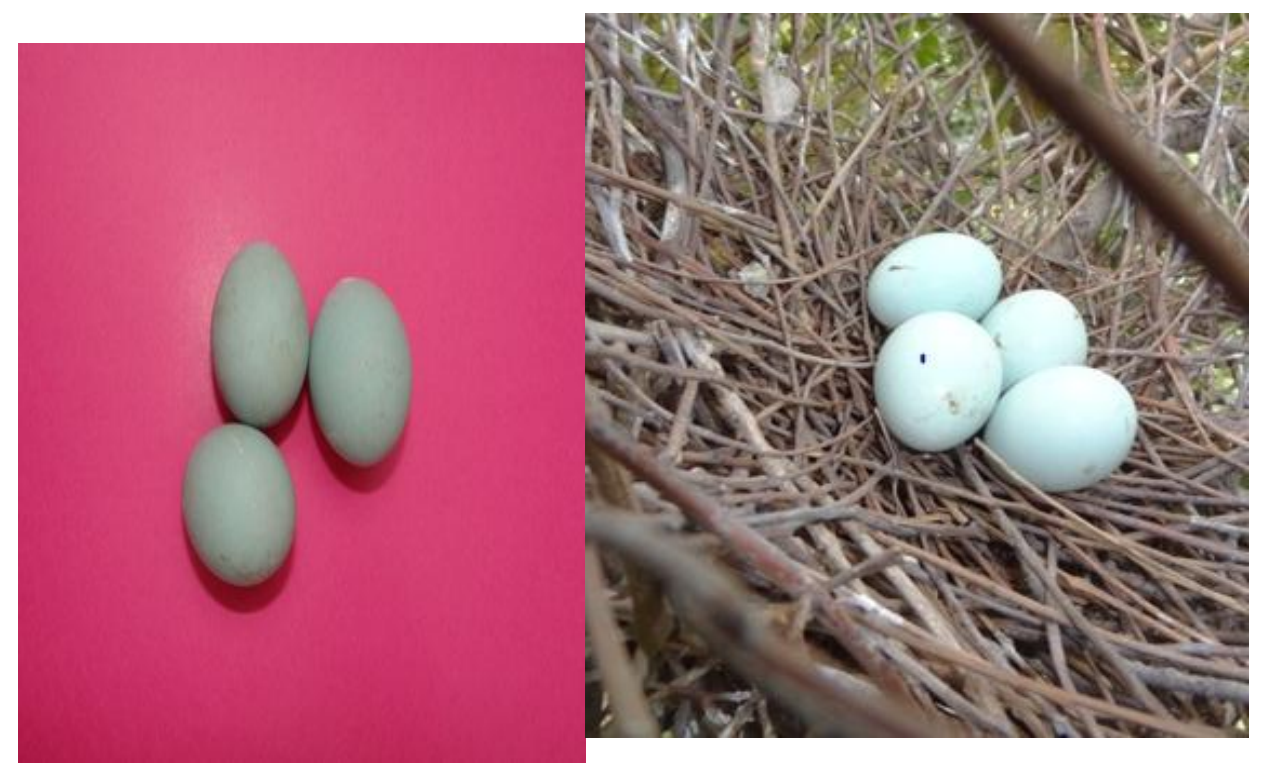

Fig. 2: Clutch size of three

Fig. 3: A nest with four eggs

\section{References:-}

1. Ali, S. and Ripley, S.D. (1969). The Handbook of the Birds of India and Pakistan together with those of Nepal, Sikkim, Bhutan and Ceylon. Vol. 2, pp. 168-170. Oxford Univ. Press, Bombay, London, New York.

2. Ali, S. and Ripley, S.D. (1983). "Handbook of the Birds of India and Pakistan". Compact Edn. Oxford Univ. Press, Delhi. pp.737.

3. Amat, J. A., Fraga, R.M. and Arroyo, G. M. (2001). Variations in body condition and egg characteristics of female Kentish Plover, Charadrius alexandrines. Ardea, 89: 293-299.

4. Amat, J. A., Fraga, R.M. and Arroyo, G. M. (2001). Intraclutch egg-size variation and offspring survival in the Kentish Plover Charadrius alexandrines. Ibis, 143:17-23.

5. Anderson, T.R. (2006). Biology of the Ubiquitous House Sparrow: From Genes to Populations. Oxford University Press.

6. Baker, E.C.S. (1929). The Fauna of British India including Ceylon and Burma. Bird Vol. VI, p. 24. Taylor and Francis, London.

7. Custer, T.W., Hensley, G.L. and Kaier, T.E. (1983). Clutch size, reproductive success and organochlorine contaminants in Atlantic coast Black-crowned Night Herons. Auk, 100: 699-710.

8. Dolenec, Z. (2004). Relationship between laying order and egg dimensions in the Blackcap Sylvia atricapilla. ActaOrnithol. (Warsaw), 39: 176-179.

9. Du B, Liu, C.J., Yang, M., Bao, S.J., Guan, M.M., Liu, N.F. (2014). Horned larks on the Tibetan Plateau adjust the breeding strategy according to the seasonal changes in the risk of nest predation and food availability. J. Avian Biol.; 45:466-74. 
10. Fazilli, M.F. (2014). Some breeding parameters in a colony of Indian Pond Herons (Ardeolagrayii). International Journal of Environmental Sciences, 3(2):60-64.

11. Flint, P.L. and Sedinger, J.S. (1992). Reproductive implications of egg-size variation in the Black Brant. Auk, 109: 896-903.

12. Grimmett, R., Inskipp, C. And Inskipp, T. (1998). Birds of the Indian Subcontinent.

13. Hill, D.A. (1984). Laying date, clutch size and egg size of the Mallard, Anasplatyrhynchos and Tufted Duck, Aythyafuligula. Ibis, 126:484-495.

14. Jaman, M.F., Hoque, N. M. D., Sarker, N.J. and Rahman, S.M.D. (2012). Ecology and breeding biology of the Pond Heron Ardeolagrayii (Sykes, 1832) and its conservation aspects. J. Asiat. Soc. Bangladesh. Sci., 38(1): 99-109.

15. Jarvinen, A. (1991). Proximate factors affecting egg volume in subarctic hole-nesting passerines. OrnisFenn., 68:99-104.

16. Klomp, A. (1970). The determination of clutch size. Ibis, 89: 302-352.

17. Kumar, A., Bhatt, D. And Joshi, V.D. (1999). Breeding ecology of Purple Sunbird, Nectariniaasiaticawith special reference to song behaviour. Ann. For., 7:192- 198.

18. Murton, R.K., Westwood, N.J., Isaacson, A.J. (1974). Factors affecting egg-weight, body weight and moult of the Wood Pigeon Columba palumbus. Ibis, 116: 52-73.

19. O’ Connor, R.J. (1979). Egg weight and brood reduction in European Swift (Apusapus). Condor, 81:133-145.

20. Panda, P.C. (1996). Shape and texture. In Textbook on egg and poultry technology, pp. 57.

21. Prather, J.W. and Cruz, A. (1995). Breeding biology of Florida Prairie Warblers and Cuban Yellow Warblers. Wilson Bull, 107: 475-484.

22. Saino, N., Romano, M., Ambrosini, R., Ferrari, R.P. and Moller, A. P. (2004). Timing of reproduction and egg quality covary with temperature in the insectivorous Barn Swallow, Hirundorustica. Funct. Ecol., 18:50-57.

23. Seedikkoya, K., Azeez, P.A. and Shukkur, E.A.A. (2008). Breeding biology of Pond Heron in Kerala, South India. Nature Proceedings.

24. Styrsky, J. D., Dobbs, R.C. and Thompson, C.F. (2002). Sources of egg-size variation in House Wrens (Troglodytes aedon): ontogenic and environmental components. Auk, 117:800-807.

25. Tremblay, J. And Ellison, L.N. (1980). Breeding success of the Black-crowned Night Heron in the St. Lawrence Estuary. Can. J. Zool., 58:1259-1263.

26. Whistler, H. (1949). "Popular handbook of Indian Birds". Gurney and Jackson, London. Pp. 40-43.

27. Yesmin, R. Rahman, K. and Haque, N. (2001). The breeding biology of the Indian Pond Heron (Ardeolagrayii) in captivity. Tigerpaper, 28(1).

28. Zhao L, Zhang X. A., Li M.C. (2002 b). Effects on nestling growth by brood manipulation in two passerine birds. Chin J. Zool.,37 (3):6-8. 